\title{
Diversity of invertebrate colonists on simple and complex substrates at hydrothermal vents on the Juan de Fuca Ridge
}

\author{
Noreen Kelly*, Anna Metaxas \\ Department of Oceanography, Dalhousie University, 1355 Oxford St., Halifax B3H 4J1, Nova Scotia, Canada
}

\begin{abstract}
This study examines the role of complex physical substrate structure on the colonization of hydrothermal vent invertebrates to test the hypothesis that the diversity of colonizing species can be enhanced by the provision of complex physical structure. Colonization was studied over 1 yr intervals between 2001 and 2003 at 2 diffuse venting sites near Axial Volcano, on the Juan de Fuca Ridge (depth $1500 \mathrm{~m}$ ), on 2 types of artificial substrates with the same planar area but different levels of structural complexity: a complex structure with interstitial spaces (sponge) and a mimic of the seafloor (basalt). Colonist assemblages were compared between substrate types using univariate and multivariate measures of community composition. While the most abundant taxa on both substrate types were gastropods and polychaetes, colonist assemblages were significantly dissimilar between substrate types, due to the greater relative abundances of polychaete and meiofaunal species colonizing sponges. Overall, the faunal assemblages colonizing sponge substrates had higher species richness, diversity and evenness than assemblages colonizing the basalts. Our results suggest that complex physical substrate structure can facilitate the colonization of a diverse faunal assemblage at diffuse hydrothermal vents on the Juan de Fuca Ridge.
\end{abstract}

KEY WORDS: Substrate complexity - Colonization ' Diversity - Richness ' Evenness · Benthic invertebrates . Hydrothermal vent · Axial Volcano

\section{INTRODUCTION}

Habitat complexity, defined as the heterogeneity in the spatial arrangement of physical structure (Lassau \& Hochuli 2004), plays a large role in facilitating species diversity, richness, and abundance in a wide array of ecosystems. In marine benthic communities, habitat complexity positively influences species diversity and facilitates species coexistence through protection from predation (Menge et al. 1985), increased food supply (Hull 1997), and/or reduction of stress (Bertness et al. 1999). In addition, complex habitat structure may facilitate colonization processes (e.g. settlement and recruitment) of associated species by increasing the area available for settlement (Eckman 1987), enhancing propagule retention (Bologna \& Heck 1999), and/or providing cues for larval settlement (Steinberg \& de Nys
2002). While habitat complexity can have positive, neutral and negative effects on associated species (Bertness et al. 1999), in environments with high physical stress the frequency of positive interactions should increase (Bertness \& Callaway 1994).

Deep-sea hydrothermal vents are ephemeral and dynamic habitats that are discontinuously distributed along the mid-ocean ridges, back-arc spreading centres and submerged volcanoes associated with island arcs. Invertebrate communities inhabiting these vents frequently experience large, rapid variations in the hydrothermal fluid that occur over small spatial (centimetres to metres) and temporal (seconds to days) scales, leading to, but not limited to, fluctuations in $\mathrm{H}_{2} \mathrm{~S}$ concentrations and temperature (Johnson et al. 1988, Chevaldonné et al. 1991). However, survival of vent faunal species ultimately depends on the properties of 
the vent fluid, which provides the energy for chemoautotrophic microbes (symbiotic and free-living), the primary producers of the ecosystem (Karl et al. 1980, Jannasch \& Mottl 1985). Thus, the most highly productive vent habitats may also present the highest levels of physiological stress for associated metazoans. The presence of complex physical structure at hydrothermal vents that could modify the path or intensity of focused hydrothermal vent fluids, thus creating a variety of microhabitats, would be expected to positively influence diversity, richness and abundance of associated species.

In the hydrothermal vent environment of the eastern Pacific, structurally complex habitats are provided by vestimentiferan tubeworms, vesicomyid clams and bathymodiolin mussels that form dense aggregations in areas of diffuse $\left(<30^{\circ} \mathrm{C}\right)$ hydrothermal fluid flow emanating from cracks in the basaltic seafloor. The tubes of vestimentiferans and shells of bivalves provide a complex structure that is inhabited by smaller vent invertebrates (Govenar et al. 2002, 2005, Van Dover 2002, 2003, Tsurumi \& Tunnicliffe 2003, Bergquist et al. 2007). On the Juan de Fuca Ridge, northeastern Pacific, small-scale (millimetres to centimetres) spatial habitat complexity is also provided by sessile colonial folliculinid ciliates ('blue mat') that secrete and dwell within chitinous tubes of 0.3 to $2 \mathrm{~mm}$ in length (Kouris et al. 2007). These tubes attach to the basalt substratum and onto each other, creating dense colonies that can cover $\sim 70 \%$ of the available surface area at diffuse vents. Compared to the surrounding non-vent basalt seafloor, higher species diversity and richness within tubeworm bushes and mussel beds (Tunnicliffe 1991, Shank et al. 1998, Govenar et al. 2005) and increased abundances of meiofauna and juvenile macrofaunal species within ciliate colonies (A. Kouris pers. comm., N. Kelly pers. obs.) have been observed. These patterns may result from increased vent fluid dispersion, which creates greater environmental, and thus niche, heterogeneity, through provision of space in close proximity to vent flows, protection from predators, and/or concentration of food resources (Sarrazin \& Juniper 1999, Van Dover 2002, 2003, Tsurumi \& Tunnicliffe 2003, Govenar et al. 2005, Govenar \& Fisher 2007).

Due to the transient and variable nature of the hydrothermal vent habitat, successful settlement and recruitment may be critical to the maintenance of vent invertebrate populations over both ecological and evolutionary timescales. To address these fundamental questions, Kelly et al. (2007) quantified patterns in invertebrate settlement and colonization at Juan de Fuca Ridge vent sites, by deploying sets of basalt blocks at vents with different flow characteristics, over different spatial (centimetres to $100 \mathrm{~km}$ ) and temporal
(1 to 2 yr) scales, and explored the biotic and abiotic factors that influenced those patterns. They found that variation in invertebrate settlement and colonization was mainly influenced by vent fluid properties (e.g. temperature and $\mathrm{H}_{2} \mathrm{~S}$ concentrations), but that biological interactions were also important in shaping colonization patterns (Kelly et al. 2007). In the present study, we continue our examination of the factors influencing colonization processes at hydrothermal vents by exploring the role of complex physical substrate structure. We analyzed colonization patterns at 2 lowtemperature diffuse vent sites (also used in Kelly et al. 2007) over 1 yr intervals on 2 types of artificial substrates with the same planar area but different levels of structural complexity: a complex structure containing interstitial spaces and a mimic of the natural basalt seafloor. While the data reported in Kelly et al. (2007) focused on spatial and temporal patterns in abundance of the 5 most abundant species colonizing only basalt substrates on an areal basis, the present study focuses on changes in the entire species assemblages based on their relative abundance between different substrate types. Specifically, we compared the species assemblages between the substrate types using univariate and multivariate measures of community composition, and related our findings to studies of species diversity in natural complex habitats in the hydrothermal vent environment and in other chemoautotrophic/chemosynthetic deep-sea systems. We predicted that the presence of complex habitat structure in the hydrothermal habitat would enhance the diversity of the colonizing assemblage, by increasing the available space for larval settlement, concentrating nutrient resources, and/or increasing subsequent juvenile survival by providing protection from predation.

\section{MATERIALS AND METHODS}

The Juan de Fuca Ridge (JdFR) in the Northeast Pacific is located 400 to $500 \mathrm{~km}$ off the west coast of North America, at the boundary of the Pacific and Juan de Fuca tectonic plates (from 44.5 to $48^{\circ} \mathrm{N}$ ). The present study was conducted at 1 ridge segment on the JdFR: Axial Volcano, located off the Oregon coast $\left(46^{\circ} \mathrm{N}, 130^{\circ} \mathrm{W}\right.$; depth $\left.\sim 1500 \mathrm{~m}\right)$. Within Axial Volcano, colonization experiments were conducted at 2 vent sites separated by $\sim 2 \mathrm{~km}$ : ROPOS $\left(45^{\circ} 55^{\prime} 59^{\prime \prime} \mathrm{N}\right.$, $\left.130^{\circ} 0^{\prime} 51^{\prime \prime} \mathrm{W}\right)$ in the ASHES vent field, and Cloud $\left(46^{\circ} 56^{\prime} 00^{\prime \prime} \mathrm{N}, 129^{\circ} 58^{\prime} 53^{\prime \prime} \mathrm{W}\right)$ located in the South Rift Zone (SRZ, Table 1). While ROPOS and Cloud were basalt-hosted, low-temperature diffuse vent sites that supported rich macrofaunal communities, ROPOS had been actively venting since at least the 1980s (Butterfield et al. 1990), while Cloud was created in the after- 
math of the 1998 eruption of Axial Volcano (Butterfield et al. 2004).

Colonization was measured between 2001 and 2003 using replicate artificial substrates attached to a single galvanized steel frame for ease of deployment and recovery with the ROV 'ROPOS'. Two types of substrate were randomly positioned across each frame: Scotch-Brite sponge pads (ca. $7.5 \times 10 \times 1.5 \mathrm{~cm}$ ) and solid basalt blocks (ca. $7 \times 10 \times 2 \mathrm{~cm})$. Both substrates presented roughly the same planar surface area (70 to $75 \mathrm{~cm}^{2}$ ) to colonizers, but the sponges were porous and thus provided the opportunity for colonization within the third dimension. Space on the sponges available for invertebrate colonization was $140 \mathrm{~cm}^{3}$, calculated as the difference between the volume of the rectangular prism, formed by the outer dimensions of the sponge (length $\times$ width $\times$ height) and the displaced volume of the sponge in water. Openings on the sponge surfaces had a mean surface area of $3.57 \mathrm{~mm}^{2}( \pm 1.73$ $\mathrm{SD}, \mathrm{n}=15$ ), while the interstitial spaces within the sponge matrix had a mean volume of $3.37 \mathrm{~mm}^{3}( \pm 2.08$ $\mathrm{SD}, \mathrm{n}=15$ ). Each substrate was held in a plastic container with holes pierced on the underside allowing for the penetration of hydrothermal fluid through (or around) the substrate, and each container was attached to the frame with a $20 \mathrm{~cm}$ galvanized steel threaded rod. Substrates within each frame were separated by a few centimetres, and thus provide independent replicates (for image see Kelly et al. 2007).

For both vent sites, 1 set of substrates was deployed in 2001, collected after 1 yr (in 2002) and replaced with a set of clean, uncolonized substrates. All remaining substrates were collected in 2003. While we were restricted to deployment periods of $1 \mathrm{yr}$ intervals, we expected that $1 \mathrm{yr}$ is a sufficient period to allow for settlement and colonization to occur. A preliminary deployment of a set of substrates for $1 \mathrm{wk}$ in 2001 at Axial Volcano yielded no settlers (A. Metaxas pers. obs.). Van Dover et al. (1988) found few recruits on hard panels after $26 \mathrm{~d}$, but observed 'significant recruitment' after $260 \mathrm{~d}$. Thus, the temporal scale in our study maximizes the probability of colonization, although it does not allow for high temporal resolution of post-settlement interactions.

Prior to recovery, point measurements of fluid temperature $\left({ }^{\circ} \mathrm{C}\right.$ above ambient) were taken with the ROV 'ROPOS' temperature probe $\left( \pm 1^{\circ} \mathrm{C}\right)$ at the level of the substrates (Table 1), and digital photographs of the surface of each substrate were taken using a SONY Cybershot digital camera. For recovery, sets of substrates were returned to the surface within Lexan boxes $(80 \times 60 \times 35 \mathrm{~cm})$ with a $5 \mathrm{~cm}$ thick layer of open cell foam glued to the underside of the lid, which ensured a snug fit to prevent the dislodgment of organisms from the substrates during transport. Upon recovery, individual substrates (and the corresponding section of foam overlying the panel) were removed from the frame, frozen at $-80^{\circ} \mathrm{C}$ aboard ship and then transferred into $95 \%$ ethyl alcohol for long-term storage. All individuals on a substrate were enumerated and identified to the lowest taxon. The number of replicate sponges substrates ( $\mathrm{n}=4$ or 6 ) was determined based on a power analysis to achieve a power of $0.8(\beta=0.2)$.

We defined as colonists the accumulated number of post-larval individuals present at the end of the recovery period. It is possible that a few individuals of mobile species may have migrated onto or away from the substrates during deployment. However, most mobile colonists recovered from the substrates were small, juvenile stages, implying their origin as settlement to the substrates rather than immigration. Of the species visible in the digital images of the substrates taken prior to recovery (generally $>2 \mathrm{~mm}$ ), counts of all individuals on substrates after recovery were higher than counts of all individuals in situ prior to recovery. This allowed us to conclude that few to no individuals were lost from the surfaces of the substrates, from both vents and deployment periods, during recovery. Recovery efficacy was similar for both sponge and basalt substrates.

The colonist assemblages present on sponge and basalt substrates from each vent site and deployment year were compared using univariate and multivariate measures of community composition. Because of the differences in structural complexity between substrates, it was not possible to obtain an objective measure of 'living space' that was comparable between substrate types and would have allowed us to standardize abundance. For example, we could not derive a realistic measure of surface area for the sponges or of volume for the basalts.

Table 1. Location, position, depth, year of deployment and length of deployment of sponge and basalt substrates. Temperature $(T)$ was measured at the level of substrates at time of recovery (listed temperatures are maximum above ambient: $\left.2.2^{\circ} \mathrm{C}\right)$. nm: not measured; SRZ: South Rift Zone

\begin{tabular}{|lccccc|}
\hline $\begin{array}{c}\text { Vent field } \\
\text { and site }\end{array}$ & $\begin{array}{c}\text { Deployment } \\
\text { year }\end{array}$ & $\begin{array}{c}\text { Latitude, } \\
\text { Longitude }\end{array}$ & $\begin{array}{c}\text { Depth } \\
(\mathrm{m})\end{array}$ & $\begin{array}{c}\text { Deployment } \\
\text { length }(\mathrm{d})\end{array}$ & $\begin{array}{c}T \\
\left({ }^{\circ} \mathrm{C}\right)\end{array}$ \\
\hline $\begin{array}{c}\text { ASHES } \\
\text { ROPOS }\end{array}$ & $2001-2002$ & $\begin{array}{c}45^{\circ} 55^{\prime} 59^{\prime \prime} \mathrm{N}, \\
130^{\circ} 00^{\prime} 50^{\prime \prime} \mathrm{W}\end{array}$ & 1550 & 362 & $\mathrm{~nm}$ \\
& $2002-2003$ & & & 409 & 8.5 \\
$\begin{array}{l}\text { SRZ } \\
\text { Cloud }\end{array}$ & $2001-2002$ & $\begin{array}{c}45^{\circ} 56^{\prime} 00^{\prime \prime} \mathrm{N}, \\
129^{\circ} 58^{\prime} 53^{\prime \prime} \mathrm{W}\end{array}$ & 1525 & 354 & 5.8 \\
& $2002-2003$ & & 410 & 5 \\
\hline
\end{tabular}


Thus, the abundance of each taxon in a replicate substrate was divided by the total abundance of individuals of all taxa in that replicate. Meiofaunal taxa (Copepoda, Ostracoda, Nematoda, Acarina; as defined by Gollner et al. 2007) were excluded from the colonist assemblages, because we were unable to identify individuals within these groups to species level. We also excluded protoconch-staged individuals of the gastropods Lepetodrilus fucensis and Depressigyra globulus, which were individuals still in the larval stage (i.e. no post-larval shell present). However, we used a separate method of analysis to compare abundance of meiofaunal species and larval gastropods between substrate types (see below).

Three different univariate diversity indices were used to characterize assemblage composition using PRIMER v.5 (PRIMER-E): species richness $(S)$, Shannon-Wiener index of species diversity $\left(H^{\prime}, \log _{\mathrm{e}}\right)$ and Pielou's evenness index $\left(J^{\prime}\right) . S$ is defined as the total number of species in the sample. $H^{\prime}$ accounts for species richness and the proportion of each species within the assemblage. $J^{\prime}$ expresses how equally individuals are partitioned among species (Clarke \& Warwick 2001). We used Student's $t$-test (assuming unequal variances) to compare $S_{1} H^{\prime}$ and $J^{\prime}$ between substrate types within each vent site and deployment year combination.

For multivariate analyses, relative abundances were fourth-root transformed to account for all levels of abundance (rare to high) prior to constructing Bray-Curtis similarity matrices. The hierarchical clustering (groupaverage linkage) technique and non-metric multidimensional scaling were used to compare the similarity of the colonist assemblages between substrate types, vent sites and deployment years. The ANOSIM (analysis of similarities) subroutine in PRIMER was used to determine significant differences in the similarity coefficient between substrate types, and between vent sites and deployment years within a substrate type. The SIMPER (similarity percentages) subroutine in PRIMER was used to evaluate which species contributed most to the dissimilarity between substrate types.

For the 10 most abundant species on sponges, rankabundance plots were generated from relative abundance averaged across replicate sponge or basalt substrates within a vent site and deployment year. Species were ranked according to decreasing abundance on sponge substrates. Rarefaction was calculated using the BioDiversity Professional Programme v.2.0 (McAleese 1997). Rarefaction computes the expected number of species [ES(n)] in a collection of $\mathrm{n}$ individuals $(n=10)$ drawn at random (without replacement) from a large pool of N individuals (Hurlbert 1971). The steeper and more elevated the curve of $n$ versus ES(n) is, the more diverse the assemblage is. Replicates were pooled across vent sites and deployment years within a substrate type.
To compare the relative abundances of meiofaunal groups (copepods and ostracods) and larval gastropod species (Lepetodrilus fucensis and Depressigyra globulus) between substrate types for each year of deployment (2001-2002 and 2002-2003), we used 2-way ANOVAs with fixed factors 'vent' and 'substrate'. Prior to analysis, relative abundance data were $\ln (x+1)$ transformed to reduce heterogeneity of variances, as detected by Levene's test.

\section{RESULTS}

Hydrothermal vent fauna colonized every set of substrates deployed at each vent site in each year. In total, 46301 ind. were collected, representing 31 taxa (Table 2), with 21 taxa shared between ROPOS and Cloud. Six species were exclusively found at ROPOS (1 gastropod, 1 bivalve, 2 polychaetes, 1 acarian, and 1 ophiuroid), while 4 species were collected only at Cloud (3 gastropods and 1 polychaete). Nineteen taxa colonized both types of substrates in at least $1 \mathrm{yr}$ and 1 vent site, whereas 8 taxa were found on both types of substrates at both vents in both years: the gastropods Lepetodrilus fucensis, Depressigyra globulus, and Provanna variabilis, the bivalve Calyptogena pacifica, the polychaetes Amphisamytha galapagensis, and Parougia wolfi, and copepods and ostracods (Table 2).

A total of 30 taxa, represented by 28809 ind., colonized the sponges, and 14 of these taxa were present at both vent sites in both deployment years (Table 2). While most meiofaunal and macrofaunal individuals were distributed throughout the interstitial spaces, polychaete worms were often found intertwined among many layers of the sponge matrix. In contrast, the basalt substrates were colonized by 17492 ind. representing 19 taxa, 8 of which were present at both vent sites in both deployment years (Table 2).

Species richness $(S)$, Shannon-Wiener diversity $\left(H^{\prime}\right)$, and Pielou's evenness $\left(J^{\prime}\right)$ indices differed significantly between substrate types (Tables $3 \& 4$ ). At both vent sites and over both deployment years, the colonist assemblages on the sponges had significantly higher species richness $(S)$ and diversity $\left(H^{\prime}\right)$ than the assemblages colonizing the basalts (Table 4). Evenness $\left(J^{\prime}\right)$ was significantly higher for the sponge than the basalt assemblages at Cloud in 2001-2002 and 2002-2003, but was not statistically different between substrate types at ROPOS in either year (Table 4). Rarefaction curves illustrated that the colonist assemblages from the sponges were more diverse, and expected to include more species per sampled number of individuals than assemblages from basalt substrates, although neither curve approached asymptotic values (Fig. 1). 
Table 2. Mean abundance $( \pm$ SD) of taxa found on sponge and basalt substrates deployed in 2001-2002 and 2002-2003 at ROPOS and Cloud vent sites at Axial Volcano, Juan de Fuca Ridge. n: number of replicate sponges or basalts at each vent site and deployment year

\begin{tabular}{|c|c|c|c|c|c|c|c|c|}
\hline \multirow[t]{3}{*}{ Taxon } & \multicolumn{4}{|c|}{$\longrightarrow$ Sponge -} & \multicolumn{4}{|c|}{$\longrightarrow$ Basalt } \\
\hline & \multicolumn{2}{|c|}{$\longrightarrow$ ROPOS -} & \multicolumn{2}{|c|}{ Cloud -} & \multicolumn{2}{|c|}{$\longrightarrow$ ROPOS- } & \multicolumn{2}{|c|}{ Cloud $\longrightarrow$} \\
\hline & $\begin{array}{l}2001-2002 \\
(\mathrm{n}=8)\end{array}$ & $\begin{array}{c}2002-2003 \\
(\mathrm{n}=4)^{\mathrm{a}}\end{array}$ & $\begin{array}{l}2001-2002 \\
(\mathrm{n}=6)^{\mathrm{a}}\end{array}$ & $\begin{array}{c}2002-2003 \\
(\mathrm{n}=4)^{\mathrm{a}}\end{array}$ & $\begin{array}{c}2001-2002 \\
(\mathrm{n}=7)^{\mathrm{b}}\end{array}$ & $\begin{array}{c}2002-2003 \\
(\mathrm{n}=8)\end{array}$ & $\begin{array}{c}2001-2002 \\
(\mathrm{n}=8)\end{array}$ & $\begin{array}{c}2002-2003 \\
(\mathrm{n}=8)\end{array}$ \\
\hline \multicolumn{9}{|l|}{ Gastropoda } \\
\hline \multicolumn{9}{|l|}{ Lepetodrilus fucensis } \\
\hline Protoconchs & $1249 \pm 625$ & $245 \pm 261$ & $138 \pm 107$ & $249 \pm 322$ & $33.4 \pm 32.4$ & $393 \pm 146$ & $70.0 \pm 105$ & $540 \pm 246$ \\
\hline Colonists & $241 \pm 120$ & $266 \pm 32.5$ & $127 \pm 52.2$ & $263 \pm 158$ & $105 \pm 75.9$ & $112 \pm 41.5$ & $120 \pm 78.3$ & $377 \pm 109$ \\
\hline \multicolumn{9}{|c|}{ 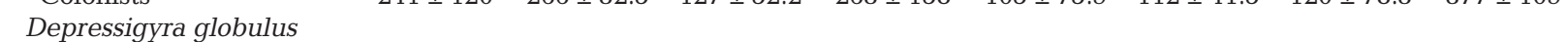 } \\
\hline Protoconchs & $91.1 \pm 38.6$ & $37.3 \pm 27.8$ & $27.8 \pm 19.7$ & $47.8 \pm 27.5$ & $7.7 \pm 9.3$ & $36.6 \pm 16.0$ & $10.4 \pm 7.8$ & $9.6 \pm 7.3$ \\
\hline Colonists & $124 \pm 81.1$ & $261 \pm 86.5$ & $47.7 \pm 23.5$ & $73.0 \pm 31.7$ & $22.0 \pm 27.6$ & $36.6 \pm 16.0$ & $3.3 \pm 1.6$ & $38.0 \pm 28.2$ \\
\hline Provanna variabilis & $11.6 \pm 4.9$ & $15.5 \pm 6.6$ & $1.5 \pm 1.0$ & $4.8 \pm 3.5$ & $5.0 \pm 3.1$ & $15.1 \pm 3.8$ & $1.0 \pm 1.1$ & $2.8 \pm 2.6$ \\
\hline Melanodrymia brightae & $0.25 \pm 0.5$ & 0 & 0 & 0 & 0 & 0 & 0 & 0 \\
\hline Temnocinclis euripes & 0 & 0 & $0.2 \pm 0.4$ & $0.3 \pm 0.5$ & 0 & 0 & 0 & $0.1 \pm 0.4$ \\
\hline Lacunoides vitreus & 0 & 0 & $0.2 \pm 0.4$ & 0 & 0 & 0 & 0 & 0 \\
\hline Clypeosectus curvus & 0 & 0 & 0 & $0.3 \pm 0.5$ & 0 & 0 & $0.5 \pm 0.5$ & $0.3 \pm 0.5$ \\
\hline Pyropelta musaica & 0 & 0 & 0 & $0.3 \pm 0.5$ & $0.1 \pm 0.4$ & 0 & 0 & 0 \\
\hline \multicolumn{9}{|l|}{ Bivalvia } \\
\hline Calyptogena pacifica & $5.6 \pm 5.7$ & $16.5 \pm 12.5$ & $4.3 \pm 7.8$ & $5.3 \pm 4.1$ & $1.4 \pm 2.1$ & $1.0 \pm 0.8$ & $0.5 \pm 0.5$ & $0.3 \pm 0.5$ \\
\hline Idas washingtonia & 0 & 0 & 0 & 0 & 0 & $0.3 \pm 0.5$ & 0 & 0 \\
\hline \multicolumn{9}{|l|}{ Aplacophora } \\
\hline Helicoradomenia juani & $0.13 \pm 0.4$ & 0 & $0.2 \pm 0.4$ & $1.3 \pm 2.5$ & 0 & 0 & 0 & 0 \\
\hline \multicolumn{9}{|l|}{ Polychaeta } \\
\hline $\begin{array}{c}\text { Amphisamytha } \\
\text { galapagensis }\end{array}$ & $73.5 \pm 29.6$ & $38.8 \pm 11.7$ & $27 \pm 7.5$ & $40.8 \pm 12.8$ & $65.7 \pm 25.8$ & $29.4 \pm 10.1$ & $21.0 \pm 11.8$ & $16.8 \pm 7.5$ \\
\hline $\begin{array}{l}\text { Ophryotrocha } \\
\text { globopalpata }\end{array}$ & $60.0 \pm 26.5$ & $23.0 \pm 16.5$ & $14.8 \pm 14.6$ & $10.8 \pm 13.5$ & $1.1 \pm 1.5$ & $0.4 \pm 0.5$ & 0 & 0 \\
\hline Hesiospina vestimentifera & 0 & $14.5 \pm 3.9$ & $16.3 \pm 3.7$ & $15.8 \pm 2.2$ & 0 & $0.1 \pm 0.4$ & $0.1 \pm 0.4$ & 0 \\
\hline Prionospio sp. & $7.5 \pm 5.7$ & $15.3 \pm 3.9$ & $26.2 \pm 9.1$ & $14.3 \pm 4.9$ & 0 & $0.1 \pm 0.4$ & 0 & 0 \\
\hline Parougia wolfi & $8.5 \pm 5.3$ & $17.0 \pm 8.2$ & $3.5 \pm 2.4$ & $7.0 \pm 5.6$ & $3.6 \pm 3.1$ & $1.6 \pm 1.3$ & $0.4 \pm 0.7$ & $1.1 \pm 1.4$ \\
\hline Amphiduropsis axialensis & 0 & $5.5 \pm 5.7$ & $3.3 \pm 2.6$ & $5.8 \pm 2.1$ & 0 & 0 & 0 & 0 \\
\hline Branchinotogluma sp. & $1.6 \pm 1.8$ & $0.3 \pm 0.5$ & $0.3 \pm 0.5$ & $0.5 \pm 1.0$ & $0.4 \pm 0.8$ & $0.3 \pm 0.5$ & 0 & $0.1 \pm 0.4$ \\
\hline Paralvinella pandorae & $1.1 \pm 1.6$ & 0 & $0.2 \pm 0.4$ & $2.0 \pm 1.8$ & 0 & 0 & 0 & 0 \\
\hline Protomystides verenae & 0 & 0 & $0.5 \pm 0.8$ & $2.3 \pm 3.2$ & 0 & $0.1 \pm 0.4$ & 0 & 0 \\
\hline Hesiodeira glabra & 0 & $0.3 \pm 0.5$ & $0.5 \pm 0.5$ & $0.3 \pm 0.5$ & 0 & 0 & 0 & 0 \\
\hline $\begin{array}{l}\text { Lepidonotopodium } \\
\text { piscesae }\end{array}$ & $0.13 \pm 0.4$ & $0.3 \pm 0.5$ & 0 & 0 & 0 & $0.1 \pm 0.4$ & 0 & 0 \\
\hline Levensteiniella kincaidi & 0 & 0 & $0.2 \pm 0.4$ & 0 & 0 & 0 & 0 & 0 \\
\hline Nereis piscesae & 0 & 0 & 0 & 0 & 0 & 0 & 0 & 0 \\
\hline \multicolumn{9}{|l|}{ Pycnogonida } \\
\hline Ammothea verenae & $0.13 \pm 0.4$ & $1.5 \pm 1.0$ & 0 & 0 & 0 & 0 & 0 & $0.1 \pm 0.4$ \\
\hline \multicolumn{9}{|l|}{ Copepoda } \\
\hline Unidentified copepod spp. & $102 \pm 64.2$ & $76.5 \pm 33.9$ & $210 \pm 164$ & $153 \pm 130$ & $6.1 \pm 5.0$ & $5.9 \pm 3.2$ & $5.5 \pm 4.4$ & $8.9 \pm 4.8$ \\
\hline \multicolumn{9}{|l|}{ Ostracoda } \\
\hline Unidentified ostracod spp. & $53.0 \pm 37.1$ & $54.0 \pm 22.7$ & $11.7 \pm 8.3$ & $55.8 \pm 6.7$ & $3.1 \pm 2.9$ & $1.1 \pm 1.0$ & $0.3 \pm 0.5$ & $2.8 \pm 2.1$ \\
\hline \multicolumn{9}{|l|}{ Acarina } \\
\hline Copidognathus papillatus & $0.25 \pm 0.5$ & 0 & 0 & 0 & 0 & 0 & 0 & 0 \\
\hline \multicolumn{9}{|l|}{ Nematoda } \\
\hline Unidentified nematode spp. & $13.4 \pm 21.4$ & 0 & $5.8 \pm 9.7$ & $5.0 \pm 7.1$ & 0 & $0.6 \pm 1.4$ & 0 & $0.6 \pm 1.2$ \\
\hline \multicolumn{9}{|c|}{ Nemertea } \\
\hline Thermanemertes valens & $2.3 \pm 4.5$ & 0 & $10.7 \pm 12.1$ & 0 & $0.6 \pm 1.0$ & 0 & 0 & 0 \\
\hline \multicolumn{9}{|l|}{ Ophiuroida } \\
\hline Unidentified ophiuroid sp. & $0.75 \pm 1.8$ & 0 & 0 & 0 & 0 & 0 & 0 & 0 \\
\hline Total number of individuals & 16559 & 4353 & 4068 & 3829 & 1789 & 4889 & 2827 & 7987 \\
\hline
\end{tabular}


Table 3. Mean (SD) univariate indices of colonist assemblage structure from sponge and basalt substrates deployed at ROPOS and Cloud vent sites between 2001-2002 and 2002-2003: N: number of individuals, $S$ : species richness, $H^{\prime}$ : Shannon-Wiener diversity, $J^{\prime}$ : Pielou's evenness. Number of replicates given in Table 2

\begin{tabular}{|lccccc|}
\hline Vent & Year & $\mathrm{N}$ & \multicolumn{1}{c}{$S$} & $H^{\prime}$ & $J^{\prime}$ \\
\hline Sponge & & & & & \\
ROPOS & $2001-2002$ & $558.3(197.4)$ & $11.38(2.00)$ & $1.57(0.17)$ & $0.65(0.07)$ \\
& $2002-2003$ & $675.0(95.3)$ & $11.75(0.50)$ & $1.49(0.10)$ & $0.60(0.03)$ \\
Cloud & $2001-2002$ & $273.7(82.2)$ & $11.33(1.03)$ & $1.64(0.15)$ & $0.67(0.05)$ \\
& $2002-2003$ & $447.5(214.5)$ & $12.25(1.89)$ & $1.44(0.18)$ & $0.58(0.09)$ \\
Basalt & & & & & \\
ROPOS & $2001-2002$ & $204.6(110.6)$ & $6.29(1.11)$ & $1.09(0.08)$ & $0.60(0.09)$ \\
& $2002-2003$ & $197.6(49.7)$ & $7.00(1.31)$ & $1.19(0.14)$ & $0.63(0.09)$ \\
Cloud & $2001-2002$ & $154.1(74.2)$ & $5.00(1.41)$ & $0.69(0.24)$ & $0.45(0.14)$ \\
& $2002-2003$ & $436.5(128.2)$ & $5.25(1.28)$ & $0.50(0.15)$ & $0.31(0.07)$ \\
\hline
\end{tabular}

Colonist assemblages from the sponge substrates clustered separately from assemblages collected from the basalt substrates, except for 2 substrates from ROPOS 20012002 (Fig. 2A). A multi-dimensional scaling (MDS) ordination also separated the colonist assemblages into 2 main groups, based on substrate type (Fig. 2B; ANOSIM: $\mathrm{R}=0.820$, $\mathrm{p}=0.001)$. Among sponge substrates, there were no significant differences in the similarity of colonist assemblages between deployment years $(R=0.167, p=0.103)$, but there was a significant difference between ROPOS and Cloud within each deployment year (2001-2002: $\mathrm{R}=0.266, \mathrm{p}=0.014 ; 2002-2003: \mathrm{R}=$ Table 4. Student's $t$-test values (degrees of freedom in parentheses) and levels of significance $\left({ }^{*} \mathrm{p}<0.05,{ }^{* *} \mathrm{p}<0.01\right.$, ${ }^{* * *} p<0.001$ ) for comparisons of univariate indices of assemblage structure from sponge and basalt substrates deployed at ROPOS and Cloud vent sites between 2001-2002 and 2002-2003. $S$ : species richness, $H^{\prime}$ : Shannon-Wiener diversity, $J^{\prime}$ : Pielou's evenness

\begin{tabular}{|llllll}
\multirow{2}{*}{ Index } & \multicolumn{3}{c}{ ROPOS } & & \multicolumn{2}{c}{ Cloud } \\
\cline { 5 - 6 } & $2001-2002$ & $2002-2003$ & & $2001-2002$ & $2002-2003$ \\
\hline$S$ & $6.196(11)^{* * *}$ & $9.029(10)^{* * *}$ & $9.683(12)^{* * *}$ & $6.671(4)^{* *}$ \\
$H^{\prime}$ & $6.848(10)^{* * *}$ & $4.146(8)^{* *}$ & & $9.370(12)^{* * *}$ & $8.952(5)^{* * *}$ \\
$J^{\prime}$ & $1.162(11)$ & $-0.608(10)$ & & $4.053(9)^{* *}$ & $5.328(5)^{* *}$
\end{tabular}

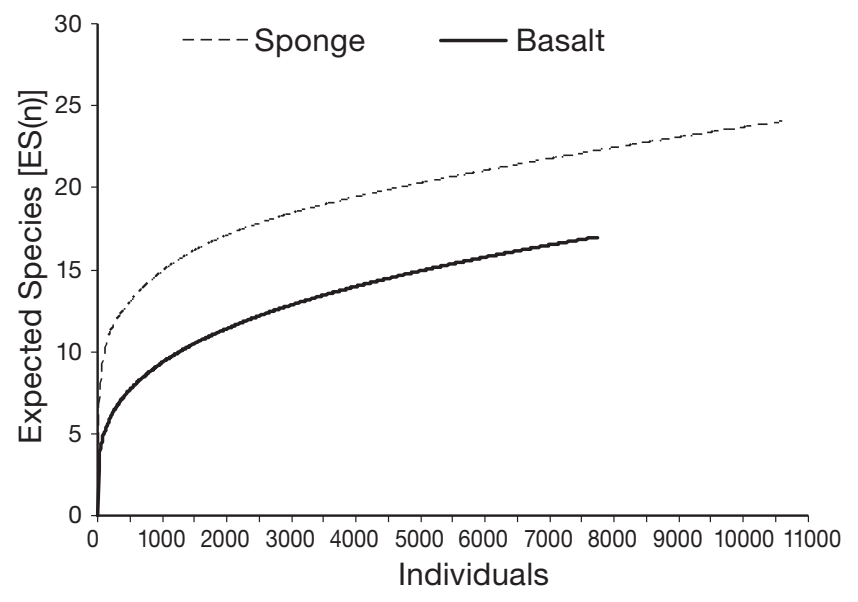

Fig. 1. Rarefaction curves for colonist assemblages on sponge and basalt substrates deployed at ROPOS and Cloud vent sites in 2001-2002 and 2002-2003. Data are pooled within each substrate grouping, as identified by multivariate analysis of colonist assemblage similarity
$0.51, p=0.029)$. Among basalt substrates, there were significant differences in the similarity of colonist assemblages between vent sites $(R=0.624, p=0.001)$ and deployment years $(\mathrm{R}=0.148, \mathrm{p}=0.011)$. The colonist assemblages from ROPOS and Cloud were significantly different within each deployment year (2001-2002: $\mathrm{R}=0.437, \mathrm{p}=0.002 ; 2002-2003: \mathrm{R}=0.787, \mathrm{p}=0.001)$, and between deployment years at ROPOS $(\mathrm{R}=0.161, \mathrm{p}=$ 0.02), but not at Cloud ( $R=0.137, p=0.072)$. The greatest differences in the colonist assemblage between sponge and basalt substrates were due to greater relative abundances of Hesiospina vestimentifera, Ophryotrocha globopalpata, Prionospio sp. and Amphiduropsis axialensis in sponges (Table 5).

For both substrates, $>98 \%$ of the assemblage was represented by $<10$ species (Fig. 3). The limpet Lepetodrilus fucensis had the greatest relative abundance on sponge and basalt substrates at both vent sites in each deployment year (Fig. 3). Species rankings were similar between substrate types, with 2 exceptions: the relative abundance of the polychaete Amphisamytha galapagensis, and to a lesser extent the gastropod Provanna variabilis, generally ranked higher on basalt substrates than on sponges. There was a more even distribution of individuals among taxa for sponges than for basalt substrates. For the sponge assemblages, 6 species accounted for $>90 \%$ of total abundance: L. fucensis, Depressigyra globulus, A. galapagensis, Ophryotrocha globopalpata, Prionospio sp. and Hesiospina vestimentifera (Fig. 3). For the basalt assemblages, 4 species accounted for $>90 \%$ of total abundance at both vent sites over both years: the gastropods L. fucensis, D. globulus, Provanna variabilis, and the polychaete A. galapagensis (Fig. 3).

There were significant differences in the relative abundance of meiofaunal groups and larval gastropod species between substrate types (Table 6). For the 


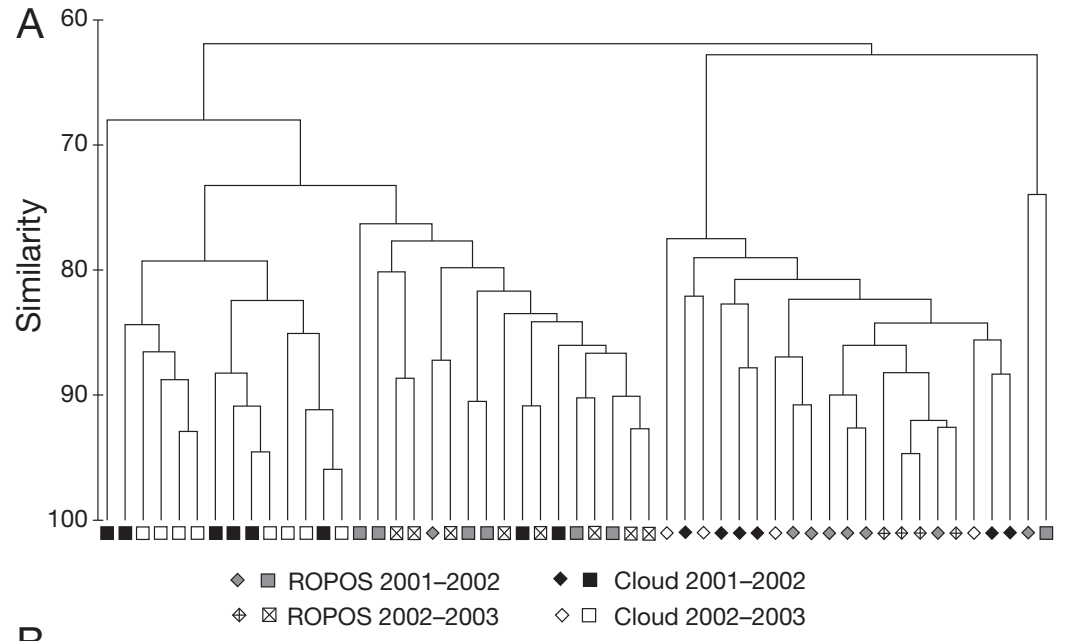

2001-2002 deployment period, relative abundance was greater on sponge than basalt substrates for all taxa examined. However, there was a significant vent $x$ substrate interaction for the larval gastropods (Table 6), and the relative abundances of larval Lepetodrilus fucensis and Depressigyra globulus were also greater on sponge than basalt substrates, but only at ROPOS (Tukey's HSD, p < 0.001). For the 20022003 deployment year, copepods, ostracods and larval D. globulus were more abundant on sponge than basalt substrates (Table 6). Although there was a significant vent $\times$ substrate interaction

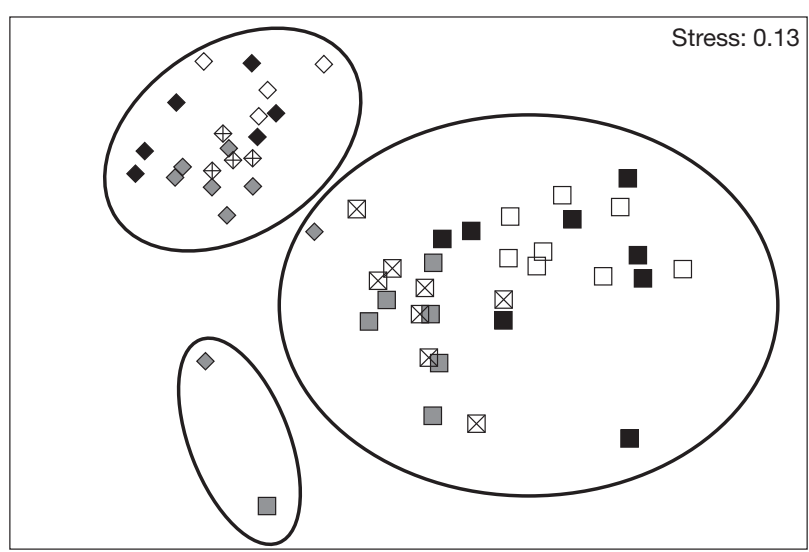

Fig. 2. (A) Hierarchical cluster dendrogram (group-average linkage) and (B) non-metric multi-dimensional scaling (MDS) plot, for colonist assemblages from sponge (diamonds) and basalt (squares) substrates deployed at ROPOS and Cloud vent sites, Axial Volcano, in 2001-2002 and 2002-2003. Solid lines bound colonist assemblages with Bray-Curtis similarity of $65 \%$, as indicated in (A). The MDS plot and cluster dendrogram were based on the Bray-Curtis similarity coefficient, calculated from standardized fourth-root transformed relative abundance data

Table 5. Species contributions to Bray-Curtis dissimilarity $(>5 \%)$ between sponge and basalt substrates deployed at ROPOS and Cloud vent sites at Axial Volcano, Juan de Fuca Ridge, in 2001-2002 and 2002-2003. Letters within parentheses indicate higher taxonomic groupings: Polychaeta $(\mathrm{P})$, Bivalvia (B) and Gastropoda (G)

\begin{tabular}{|lcc|}
\hline Species & $\begin{array}{c}\text { Contribution } \\
(\%)\end{array}$ & $\begin{array}{c}\text { Cumulative } \\
(\%)\end{array}$ \\
\hline Hesiospina vestimentifera (P) & 13.74 & 13.74 \\
Ophryotrocha globopalpata (P) & 13.05 & 26.79 \\
Prionospio sp. (P) & 12.62 & 39.41 \\
Amphiduropsis axialensis (P) & 8.92 & 48.34 \\
Calyptogena pacifica (B) & 6.39 & 54.73 \\
Parougia wolfi (P) & 6.16 & 60.89 \\
Provanna variabilis (G) & 5.49 & 66.38 \\
Depressigyra globulus (G) & 5.43 & 71.81 \\
\hline
\end{tabular}

for larval L. fucensis, its relative abundance was also greater on sponge than basalt substrates at both ROPOS and Cloud vents (Tukey's HSD, p < 0.01).

\section{DISCUSSION}

Complex physical substrate structure appears to augment the colonization of invertebrate species at Axial Volcano diffuse vent sites. While both sponge and basalt substrates provided artificial environments for colonization by vent species, the sponge substrates simulated a complex habitat. This scale of complexity can be found in the natural environment within tightly woven Ridgeia piscesae tubeworm bushes (Tsurumi \& Tunnicliffe 2003) or the dense colonies of folliculinid ciliates, Folliculinopsis sp. ('blue mat'; Kouris et al. 2007). The faunal assemblages that colonized sponge substrates had higher abundance, diversity and evenness than assemblages that colonized the basalt substrates. While gastropods and polychaetes were the numerically dominant faunal groups of colonists on both types of substrates, the increased structural complexity provided by the sponges also contributed to the successful colonization of smaller polychaete species (Parougia wolfi, Ophryotrocha globopalpata, Hesiospina vestimentifera), larval gastropods and meiofaunal taxa (copepods, ostracods). In a recent study, Govenar \& Fisher (2007) documented similar epifaunal species richness and composition among artificial and natural tubeworm aggregations on the East Pacific Rise (EPR). The results of these 2 studies imply that complex physical structures have an important role in regulating invertebrate assemblages at diffuse hydrothermal vents.

The structural complexity of the sponge substrates could have resulted in increased diversity, abundance and richness of the colonist assemblage through several mechanisms. The interstitial spaces of sponges can provide an increased amount of 'living space' for certain 

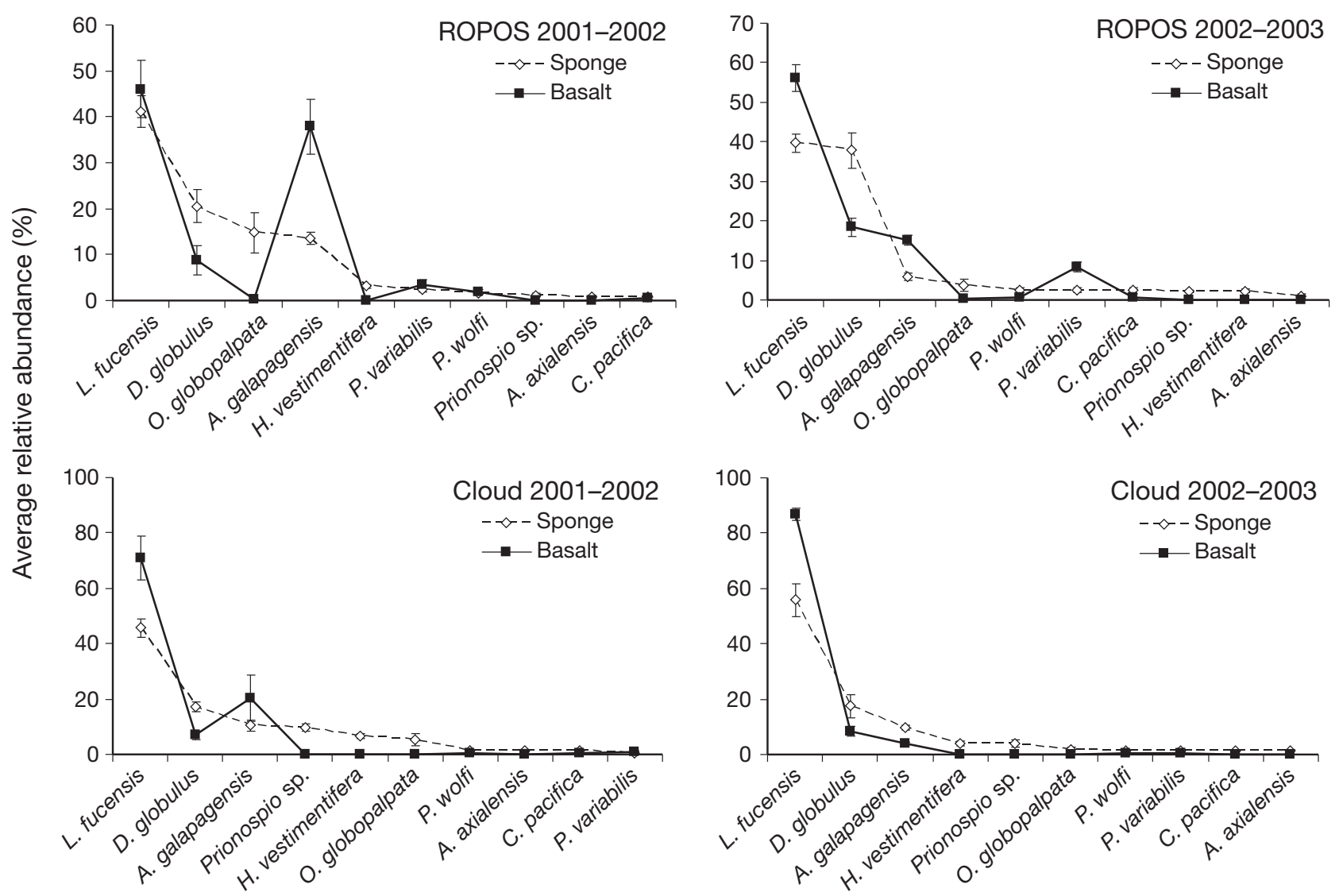

Fig. 3. Rank-abundance curves for the 10 most abundant taxa collected from sponge and basalt substrates deployed at ROPOS and Cloud vent sites between 2001-2002 and 2002-2003. Data points represent mean ( \pm SE) relative abundance (\%) of individuals.

$\mathrm{N}$ and full species names are given in Table 2. Species are ranked according to decreasing abundance on sponge substrates

taxa of colonists, increasing the total area available for larval settlement, but also providing protection from predation and enhancing subsequent survival. Bacterial mats were growing throughout, and large amounts of particulate organic material accumulated in most

Table 6. F-values of 2-way ANOVA examining variation in relative abundance of 2 meiofaunal groups (copepods and ostracods) and 2 species of larval gastropods (Lepetodrilus fucensis and Depressigyra globulus) between basalt and sponge substrate types at ROPOS and Cloud vent sites, for the 2001-2002 and 2002-2003 deployment periods. df: degrees of freedom; ${ }^{*} p<0.01,{ }^{* *} p<0.001$

\begin{tabular}{|lccccccc|}
\hline \multirow{2}{*}{ Year } & \multirow{2}{*}{ Taxon } & \multicolumn{7}{c}{ Factor } \\
\cline { 3 - 8 } & & \multicolumn{2}{c}{ Vent } & \multicolumn{2}{c|}{ Substrate } & \multicolumn{2}{c|}{ Vent $\times$ Substrate } \\
& $F$ & df & $F$ & df & $F$ & df \\
\hline $2001-2002$ Copepoda & $41.1^{*}$ & 1,25 & $102^{* *}$ & 1,25 & 1.10 & 1,25 \\
& Ostracoda & 0.133 & 1,25 & $5.92^{*}$ & 1,25 & 0.337 & 1,25 \\
L. fucensis & 4.12 & 1,25 & $74.9^{* *}$ & 1,25 & $61.2^{* *}$ & 1,25 \\
D. globulus & 2.47 & 1,25 & $65.0^{* *}$ & 1,25 & $18.6^{* *}$ & 1,25 \\
$2002-2003$ Copepoda & $10.7^{* *}$ & 1,20 & $118^{* *}$ & 1,20 & 0.003 & 1,20 \\
& Ostracoda & $11.0^{* *}$ & 1,20 & $655^{* *}$ & 1,20 & 0.950 & 1,20 \\
L. fucensis & $49.4^{* *}$ & 1,20 & 5.58 & 1,20 & $49.8^{* *}$ & 1,20 \\
D. globulus & $9.16^{* *}$ & 1,20 & $61.7^{* *}$ & 1,20 & 0.599 & 1,20 \\
\hline
\end{tabular}

sponges (N. Kelly pers. obs.). These bacterial mats and particulates may have provided nutritional resources for grazers and deposit feeders (Bergquist et al. 2007). The complex structures in our study may have also decreased competition for food resources among grazers, scavengers and deposit feeders by concentrating food resources.

The abundance and diversity of invertebrate species inhabiting the natural basaltic seafloor are typically lower than in adjacent tubeworm bushes (Tunnicliffe 1991, Shank et al. 1998, Govenar et al. 2005). In our study, the basalt substrates represented a less complex substrate than the sponges with few pits or crevices and little refuge from predators. Thus, settling invertebrates may have been exposed to higher rates of competition or predation. Space is an important resource for grazers, allowing access to microbial food sources (Tsurumi \& Tunnicliffe 2003). Gastropod grazers comprised 2 
of the 3 numerically dominant species on basalt substrates at both ROPOS and Cloud, and the limpet Lepetodrilus fucensis was the most abundant species at both vent sites in both deployment years. Accidental mortality (e.g. 'bulldozing') of sessile recruits by gastropods has been inferred at low temperature vents on the East Pacific Rise (Micheli et al. 2002). In combination, accidental 'bulldozing' of recently settled colonists, especially of rare species (Micheli et al. 2002, Govenar \& Fisher 2007, Kelly et al. 2007), and the numerical dominance of the limpet L. fucensis, could lead to a decrease in species diversity and richness on basalt substrates.

On both the basalt and sponge substrates, few species $(\leq 6)$ comprised $>90 \%$ of the total abundance of colonists, but 3 species consistently were numerically dominant: the gastropods Lepetodrilus fucensis and Depressigyra globulus, and the polychaete Amphisamytha galapagensis. These 3 species are highly abundant and widely distributed across the Juan de Fuca Ridge system (Tsurumi \& Tunnicliffe 2001, 2003), and occupy several habitats with differing physico-chemical conditions (Sarrazin \& Juniper 1999). As these species appear to have broad niches and can exploit a wide range of resources (Bergquist et al. 2007), complex habitat structure may not be required for the successful colonization of these particular species in the vent environment. In contrast, habitat complexity appears to be particularly important for most species of polychaetes at Axial Volcano vents. Approximately $50 \%$ of the dissimilarity in colonist assemblages between substrate types was due to the greater colonization of 4 polychaete species on sponges than on basalt substrates (Table 5). Based on their stable isotope signatures, 3 of these 4 species (Hesiospina vestimentifera, Ophryotrocha globopalpata, Amphiduropsis axialensis) are presumed to be specialist predators in the Juan de Fuca vent system (Bergquist et al. 2007). Complex habitat structure may facilitate the colonization of species with narrow dietary requirements by concentrating prey resources for these specialists.

Differences in colonist assemblages were detected between vent sites and, less frequently, between deployment years for both substrate types. These differences were mainly due to the differential colonization of uncommon or rare species of gastropods and polychaetes between vent sites or deployment years (Table 2). This differential colonization may be the result of spatial and temporal variability in larval supply (e.g. Metaxas 2004) and/or settlement (e.g. Kelly et al. 2007). Exposure to vent fluid is also an important factor influencing faunal composition at vent sites on the Juan de Fuca Ridge (Sarrazin et al. 1999), which can vary spatially and temporally due to variations in turbulent mixing, tides and bottom currents (Johnson et al. 1988, Tivey et al. 2002). The temperature (an approximate measure of hydrothermal fluid exposure; Johnson et al. 1988) measured at the level of the substrates (20 cm above the vent opening) prior to recovery varied by $\sim 0.5^{\circ} \mathrm{C}$ at Cloud and $\sim 1.3^{\circ} \mathrm{C}$ at ROPOS over 5 min (degrees Celsius above ambient; N. Kelly pers. obs.), suggesting that colonists experienced frequent variations in vent fluid exposure within and between vent sites over the course of 1 yr. Also, differences in flow vigour, mineral deposition and the morphologies of bacterial films on substrates, between vent sites were evident from visual observations of substrates in 2002 and 2003. Variations in flow vigour (Sarrazin et al. 1999) and mineral deposition (Tunnicliffe \& Fontaine 1987) may have inhibited colonization of some species with low physiological tolerances to higher temperatures, $\mathrm{H}_{2} \mathrm{~S}$ concentrations, and/or anoxic conditions, while differences in microbial assemblages on the substrates could have consequences for the abundance and diversity of primary consumers if the nutritional quality varies among assemblages.

Species diversity and evenness of colonist assemblages from sponge substrates were within the range of those reported for macrofaunal assemblages associated with hydrothermal vent tubeworm bushes on the JdFR and EPR, although in our study, species richness values were generally lower (Tsurumi \& Tunnicliffe 2001, 2003, Govenar et al. 2002, 2005). Lower species richness in sponges compared to other complex vent habitats may be related to the smaller spatial extent of sponges, as estimates of richness can be sensitive to sample volume (Colwell \& Coddington 1994). Differences in richness may also be attributed to the age of species assemblages, as the sponge assemblages in our study were $\leq 1 \mathrm{yr}$ old compared to those in other studies. Previous studies have recorded significant recruitment to new vents within 1 yr (e.g. Tunnicliffe et al. 1997), but a 'mature' vent assemblage may take several years to develop (Shank et al. 1998, Tsurumi \& Tunnicliffe 2003). With increasing age of an assemblage, the colonization of uncommon, rare, or late successional species could eventually be added to the community, resulting in higher species richness.

The increased habitat complexity provided by the artificial sponges had a positive effect on species diversity and co-existence at JdFR vent sites. Similarly, the increase in niche heterogeneity, and thus the increase of trophic pathways, or provision of refuge from predation, also appear to increase species diversity over background levels at other deep-sea reducing environments (Baco \& Smith 2003, Bergquist et al. 2003). However, a relatively greater increase in diversity due to complexity has been recorded particularly at whale falls, but also at cold seeps, respectively, than at vents. Whale skeletons provide physical habitat structure as well as a long-last- 
ing source of nutrition for multiple trophic guilds of associated species (Smith \& Baco 2003). In contrast, vestimentiferan tubeworms at vents and seeps appear to provide little (direct) nutrition for associated species (Micheli et al. 2002, Bergquist et al. 2007), and the folliculinid ciliate colonies ('blue mat') at JdFR vents appear to be a source of nutrition for only 1 specialized gastropod species (Bergquist et al. 2007). While the artificial sponge matrix we used did not provide a source of nutrition for associated species either, the greater accumulation of detritus and surface area for growth of microbial films likely provided several important nutrient pathways for primary consumers (e.g. Bergquist et al. 2007). In addition, vent species must cope with the fluctuating and unpredictable supply of hydrothermal fluid (Johnson et al. 1988, Sarrazin et al. 1999, Butterfield et al. 2004), and a higher frequency and magnitude of disturbance (e.g. Tunnicliffe \& Juniper 1990) than at cold seeps or whale falls (e.g. Sibuet \& Olu 1998, Smith \& Baco 2003). Thus, the positive effects of habitat complexity, facilitating higher species abundance and diversity, may be less effective at hydrothermal vents, since the habitatproviding species are themselves also affected by the harsh and unstable vent habitat conditions, restricting the number of associated species capable of exploiting these productive environments.

In summary, our findings suggest that habitat complexity plays an important role in influencing species diversity, richness and abundance at hydrothermal vents. Using artificial substrates with the same planar surface area but varying in spatial complexity, we demonstrated that the increased complexity of the sponge substrates resulted in increased diversity, richness and evenness of the colonizing species assemblages, compared to the less structured environment of the basalt blocks. However, this structure may be more important in increasing juvenile survivorship of small and rare specialists, than for species with broader ecological niches. Our results suggest that complex physical substrate structure can influence the diversity of colonist assemblages at diffuse hydrothermal vents on the Juan de Fuca Ridge.

Acknowledgements. We thank the crews of the RV 'Thomas G. Thompson', CCGS 'John P. Tully', and ROV 'ROPOS' for their assistance during deployment and recovery of many sets of experiments. We also thank chief scientists V. Tunnicliffe, K. Juniper, B. Embley, W. Chadwick, and J. Delaney for their patience and willingness to conduct these experiments during cruises with many time constraints. A. Warén provided valuable information on gastropod identification. B. Schofield helped design and construct blocks and frames. Finally, we thank Dr. R. Scheibling and 3 anonymous reviewers for their critical review of earlier versions of this manuscript. This research was supported by NSERC PGS D and Izaak Walton Killam Memorial Scholarships to N.K., and NSERC Discovery and CRO grants to A.M.

\section{LITERATURE CITED}

Baco AR, Smith CR (2003) High species richness in deep-sea chemoautotrophic whale skeleton communities. Mar Ecol Prog Ser 260:109-114

Bergquist DC, Warda T, Cordes EE, McNelisa T and others (2003) Community structure of vestimentiferan-generated habitat islands from Gulf of Mexico cold seeps. J Exp Mar Biol Ecol 289:197-222

Bergquist DC, Eckner JT, Urcuyo IA, Cordes EE, Hourdez S, Macko SA, Fisher CR (2007) Using stable isotopes and quantitative community characteristics to determine a local hydrothermal vent food web. Mar Ecol Prog Ser 330:49-65

> Bertness MD, Callaway R (1994) Positive interactions in communities: a post cold war perspective. Trends Ecol Evol 9: 191-193

Bertness MD, Leonard GH, Levine JM, Schmidt PR, Ingraham AO (1999) Testing the relative contribution of positive and negative interactions in rocky intertidal communities. Ecology 80:2711-2726

Bologna PAX, Heck KL Jr (1999) Macrofaunal associations with seagrass epiphytes: relative importance of trophic and structural characteristics. J Exp Mar Biol Ecol 242: 21-39

Butterfield DA, Massoth GJ, McDuff RE, Lupton JE, Lilley MD (1990) Geochemistry of hydrothermal fluids from Axial Seamount Hydrothermal Emissions Study vent field, Juan de Fuca Ridge: subseafloor boiling and subsequent fluid-rock interaction. J Geophys Res 95:12895-12921

Butterfield DA, Lilley MD, Huber JA, Baross JA, Roe KK, Embley RW, Massoth GJ (2004) Mixing, reaction, and microbial activity in the sub-seafloor revealed by temporal and spatial variation in diffuse flow vents at Axial Volcano. In: Wilcock WSD, DeLong EF, Kelley DS, Baross JA, Cary SC (eds) The subseafloor biosphere at mid-ocean ridges. American Geophysical Union, Washington, DC, p 269-289

- Chevaldonné P, Desbruyères D, Le Haître M (1991) Timeseries of temperature from three deep-sea hydrothermal vent sites. Deep-Sea Res 38:1417-1430

Clarke KR, Warwick RM (2001) Change in marine communities: an approach to statistical analysis and interpretation. PRIMER-E Ltd, Plymouth

Colwell RK, Coddington JA (1994) Estimating terrestrial biodiversity through extrapolation. Philos Trans R Soc Lond B 345:101-118

Eckman JE (1987) The role of hydrodynamics in recruitment, growth, and survival of Agropecten irradians (L.) and Anomia simplex (D'orbigny) within eelgrass meadows. J Exp Mar Biol Ecol 106:165-191

Gollner S, Zekely J, Govenar B, Le Bris N, Nemeschkal HL, Fisher CR, Bright M (2007) Tubeworm-associated permanent meiobenthic communities from two chemically different hydrothermal vent sites on the East Pacific Rise. Mar Ecol Prog Ser 337:39-49

- Govenar B, Fisher CR (2007) Experimental evidence of habitat provision by aggregations of Riftia pachyptila at hydrothermal vents on the East Pacific Rise. PSZN I: Mar Ecol 28:3-14

Govenar BW, Bergquist DC, Urcuyo IA, Eckner JT, Fisher CR (2002) Three Ridgeia piscesae assemblages from a single Juan de Fuca Ridge sulphide edifice: structurally different and functionally similar. Cah Biol Mar 43:247-252

> Govenar B, Le Bris N, Gollner S, Glanville J, Aperghis AB, Hourdez S, Fisher CR (2005) Epifaunal community structure associated with Riftia pachyptila aggregations in chemically different hydrothermal vent habitats. Mar Ecol Prog Ser 305:67-77 
Hull SL (1997) Seasonal changes in diversity and abundance of ostracods on four species of intertidal algae with differing structural complexity. Mar Ecol Prog Ser 161:71-82

Hurlbert SH (1971) The nonconcept of species diversity: a critique and alternative parameters. Ecology 52:577-586

Jannasch HW, Mottl MJ (1985) Geomicrobiology of deep-sea hydrothermal vents. Science 229:717-723

Johnson KS, Childress JJ, Beehler CL (1988) Short-term temperature variability in the Rose Garden hydrothermal vent field: an unstable deep-sea environment. Deep-Sea Res 35:1711-1721

Karl DM, Wirsen CO, Jannasch HW (1980) Deep-sea primary production at the Galápagos hydrothermal vents. Science 207:1345-1347

Kelly NE, Metaxas A, Butterfield DA (2007) Spatial and temporal patterns in colonization of deep-sea hydrothermal vent invertebrates on the Juan de Fuca Ridge, NE Pacific. Aquat Biol 1:1-16

Kouris A, Juniper SK, Frébourg G, Gaill F (2007) Protozoanbacterial symbiosis in a deep-sea hydrothermal vent folliculinid ciliate (Folliculinopsis sp.) from the Juan de Fuca Ridge. PSZN I: Mar Ecol 28:63-71

Lassau SA, Hochuli DF (2004) Effects of habitat complexity on ant assemblages. Ecography 27:157-164

McAleese N (1997) BioDiversity professional programme, V2.0. The Natural History Museum \& The Scottish Association for Marine Science, Oban

Menge BA, Lubchenco J, Ashkenas LR (1985) Diversity, heterogeneity and consumer pressure in a tropical rocky intertidal community. Oecologia 65:394-405

Metaxas A (2004) Spatial and temporal patterns in larval supply at hydrothermal vents on the northeast Pacific Ocean. Limnol Oceanogr 49:1949-1956

Micheli F, Peterson CH, Mullineaux LS, Fisher CR and others (2002) Predation structures: communities at deep-sea hydrothermal vents. Ecol Monogr 72:365-382

Sarrazin J, Juniper SK (1999) Biological characteristics of a hydrothermal edifice mosaic community. Mar Ecol Prog Ser 185:1-19

Sarrazin J, Juniper SK, Massoth G, Legendre P (1999) Physical and chemical factors influencing species distributions on hydrothermal sulphide edifices of the Juan de Fuca Ridge, northeast Pacific. Mar Ecol Prog Ser 190: 89-112

Shank TM, Fornari DJ, Von Damm KL, Lilley MD, Haymon

Editorial responsibility: Judith Grassle,

New Brunswick, New Jersey, USA
RM, Lutz RA (1998) Temporal and spatial patterns of biological community development at nascent deep-sea hydrothermal vents. Deep-Sea Res II 45:465-515

Sibuet M, Olu K (1998) Biogeography, biodiversity and fluid dependence of deep-sea cold-seep communities at active and passive margins. Deep-Sea Res II 45:517-567

Smith CR, Baco A (2003) Ecology of whale falls at the deepsea floor. Oceanogr Mar Biol Annu Rev 41:311-354

Steinberg PD, de Nys R (2002) Chemical mediation of colonization of seaweed surfaces. J Phycol 38:621-629

> Tivey MK, Bradley AM, Joyce TM, Kadko D (2002) Insights into tide-related variability at seafloor hydrothermal vents from time-series temperature measurements. Earth Planet Sci Lett 202:693-707

Tsurumi M, Tunnicliffe V (2001) Characteristics of a hydrothermal vent assemblage on a volcanically active segment of Juan de Fuca Ridge, northeast Pacific. Can J Fish Aquat Sci 58:530-542

Tsurumi M, Tunnicliffe V (2003) Tubeworm-associated communities at hydrothermal vents on the Juan de Fuca Ridge, northeast Pacific. Deep-Sea Res I 50:611-629

Tunnicliffe V (1991) The biology of hydrothermal vents: ecology and evolution. Oceanogr Mar Biol Annu Rev 29: 319-407

Tunnicliffe V, Fontaine AR (1987) Faunal composition and organic surface encrustations at hydrothermal vents on the southern Juan de Fuca Ridge. J Geophys Res 92: 11303-11314

Tunnicliffe V, Juniper SK (1990) Dynamic character of the hydrothermal vent habitat and the nature of the sulphide chimney fauna. Prog Oceanogr 24:1-13

> Tunnicliffe V, Embley RW, Holden JF, Butterfield DA, Massoth BJ, Juniper SK (1997) Biological colonization of new hydrothermal vents following an eruption on Juan de Fuca Ridge. Deep-Sea Res I 44:1627-1644

> Van Dover CL (2002) Community structure of mussel beds at deep-sea hydrothermal vents. Mar Ecol Prog Ser 230: 137-158

> Van Dover CL (2003) Variation in community structure within hydrothermal vent mussel beds of the East Pacific Rise. Mar Ecol Prog Ser 253:55-66

Van Dover CL, Berg CJ Jr, Turner RD (1988) Recruitment of marine invertebrates to hard substrates at deep-sea hydrothermal vents on the East Pacific Rise and Galapagos spreading center. Deep-Sea Res 35:1833-1849

Submitted: July 12, 2007; Accepted: July 10, 2008

Proofs received from author(s): August 27, 2008 